\title{
Assemblages of drosophilids (Diptera, Drosophilidae) in mangrove forests: community ecology and species diversity
}

\author{
Hermes J. Schmitz ${ }^{1}$, Paulo R. P. Hofmann ${ }^{2} \&$ Vera L. S. Valente ${ }^{1,3}$
}

1. Programa de Pós-Graduação em Biologia Animal, Laboratório de Drosophila, Instituto de Biociências, Universidade Federal do Rio Grande do Sul, Av. Bento Gonçalves, 9500, Bloco B, Prédio 43323, sala 210, Agronomia, Caixa Postal 15053, $91501-970$ Porto Alegre, RS, Brazil. (hj.schmitz@gmail.com; vera.gaiesky@ufrgs.br)

2. Departamento de Biologia Celular, Embriologia e Genética, Centro de Ciências Biológicas, Universidade Federal de Santa Catarina (UFSC), Campus Universitário, Trindade, Caixa Postal 476, 88010-970 Florianópolis, SC, Brazil. (prph@ccb.ufsc.br) 3. Departamento de Genética, Instituto de Biociências, Universidade Federal do Rio Grande do Sul. Porto Alegre, RS, Brazil.

\begin{abstract}
Brazilian fauna of drosophilids has been researched in various ecosystems, but those in mangrove forests remain overlooked in Brazil and elsewhere. The present study attempts to characterise the assemblages of drosophilids of this environment, based on 28 collections taken in three mangrove areas in Santa Catarina Island, southern Brazil. The three mangroves surveyed were different in their surroundings, which varied from highly urbanised areas to conservation areas with natural vegetation. Overall, 69 species were collected, and no remarkable difference was detected in species composition and abundances or in the richness, evenness and heterogeneity between sites. The species abundance distribution observed fitted to a theoretical lognormal distribution in the three mangroves. The species richness scored and the performance of the species richness estimators showed an unexpectedly high diversity, considering the very low floristic diversity and the harsh conditions of the environment. Regarding species composition and abundances, the drosophilid mangrove assemblages were shown to be more similar to those found in open environments, with a marked dominance of exotic species. Finally, considering the apparent lack of feeding and breeding sites, we suggest that mangrove forests are acting as sink habitats for the drosophilids populations.
\end{abstract}

KEYWORDS. Biodiversity, diversity measures, Drosophila, Neotropical region, source-sink hypothesis.

RESUMO. Assembléias de drosofilídeos (Diptera, Drosophilidae) em manguezais: ecologia de comunidades e diversidade de espécies. A fauna brasileira de drosofilídeos tem sido estudada em vários ecossistemas, mas os manguezais têm sido negligenciados a esse respeito no Brasil e em todo o mundo. O presente estudo traz uma caracterização das assembléias de drosofilídeos neste ambiente, baseando-se em 28 coletas realizadas em três áreas de manguezais na ilha de Santa Catarina, sul do Brasil. Os três manguezais estudados apresentam diferenças marcantes quanto aos ambientes que os cercam, desde regiões altamente urbanizadas até áreas de proteção ambiental com vegetação natural. Ao todo, 69 espécies foram coletadas, e nenhuma diferença marcante foi detectada na composição e abundância das espécies, bem como na riqueza, equitabilidade e heterogeneidade entre os locais. A distribuição de abundância de espécies encontrada ajustou-se a uma distribuição teórica lognormal nos três manguezais. A riqueza de espécies observada e o desempenho de estimadores de riqueza de espécies mostraram uma inesperada alta diversidade, considerando a baixa diversidade florística e as condições hostis do ambiente. A respeito da composição e abundância de espécies, as assembléias de drosofilídeos dos manguezais mostraram-se mais similares àquelas encontradas em ambientes relativamente mais abertos, com grande dominância de espécies exóticas. Finalmente, considerando-se a aparente escassez de sítios de alimentação e oviposição do ambiente, sugere-se que os manguezais estejam agindo como "sink habitats" para as populações de drosofilídeos.

PALAVRAS-CHAVE. Biodiversidade, hipótese source-sink, medidas de diversidade, Drosophila, Região Neotropical.

Mangrove forests form a very peculiar ecosystem that covers tropical and subtropical intertidal plains all over the world, and are areas of contact between the terrestrial and marine environments and their respective biotas. These forests are swampy, dominated by the tidal regime, and are subject to periodical flooding, have high levels of salinity, and present muddy and poorly oxygenated soil (CINTRÓN \& SCHAEFFER-NovelLi, 1980). Floristic diversity in mangroves is markedly low, with only facultative halophytic trees that underwent extreme adaptations to live in this unique environment, where other plants cannot resist. Unfortunately, this ecosystem constitutes one of the most threatened environments of the world, suffering accelerated deforestation and human impact, even bigger than those experienced by the tropical rain forests. In approximately two decades, nearly one third of the mangrove forests of the world were lost (VALIELA et al., 2001). Notwithstanding this alarming condition, mangroves do not receive the same attention from the media and conservation groups as do equally threatened but more charismatic environments. As a result, the ecological and evolutionary processes operating in such a distinctive forest remain mostly unknown.

On the other hand, flies of the genus Drosophila Fallén, 1823 have been used intensively in several areas of study. The solution for many genetic and evolutionary problems must be found within an adequate ecological framework, but this area of study has received less attention (SHORROCKS, 1975). CARSON (1971) provided an ecological definition of such flies as being primary consumers of yeasts and bacteria, microorganisms associated with the initial stages of plant material decay. DOBZHANSKY \& PAVAN (1950) emphasized the big diversity of the Brazilian Drosophila fauna, and demonstrated that the abundances of the species vary significantly in space and time.

KRIJGER (2000) stated that explaining the local species diversity represents a major challenge faced by 
ecological science, and that the factors and processes that maintain the number of species in a given locality, in most cases, remain unknown. For example, local communities are open and coupled to broader landscapes via immigration and emigration of individuals and, at community level, such flows permit species sustained in one habitat to persist locally in other habitats, despite a trend towards exclusion (HoLt et al., 2003). This can generate a source-sink system. In a source population, the number of births exceeds the number of deaths and the number of emigrants exceeds the number of immigrants. Such source populations may support sink populations in other habitats, where the deaths exceed the births, and immigrants exceed emigrants, which would otherwise be unable to persist (PULLIAM, 1988; WATKINSON \& Sutherland, 1995; Thomas \& Kunin, 1999). This effect can increase the species diversity of some habitats in heterogeneous landscapes (SCHMIDA \& WILSON, 1985).

Drosophilid communities were already pointed as excellent models to the study of the effect of the environmental heterogeneity on species diversity (KriJger, 2000). Cunha \& Magalhães (1965) underlined the importance of studying tropical assemblages of Drosophila as an opportunity to compare organisms of the same group living in environments that offer different conditions. The highly heterogeneous landscapes of the Neotropical region are associated with the immense biodiversity it presents. The Brazilian drosophilid fauna is highly diverse (SENE et al., 1980; VAL et al., 1981), and has been researched in different types of environments. The heterogeneous nature of Santa Catarina Island, in southern Brazil, has been surveyed as an opportunity to compare drosophilid assemblages in different environments of the same region, especially the Atlantic rainforest and the urban environment (DE TONI \& Hofmann, 1995; De Toni et al., 2007; Gottschalk et al., 2007). In this context, in a previous study (SchmiTz et al., 2007), we conducted a taxonomic survey of the Drosophilidae fauna present in the mangrove forests of Santa Catarina Island, an environment not surveyed before anywhere. In the present one, our main objectives were: (1) to characterise the species abundances and diversity measures of mangrove drosophilid assemblages, and (2) to investigate their spatial variation, considering mangrove forests located in the same region but differing in their surroundings. Regarding this last objective, we considered two alternative hypotheses: (1) species abundances and diversity measures of mangrove drosophilid assemblages respond to the differences in the environments surrounding the mangroves; and (2) mangrove forests of the same region have typical drosophilid assemblages, not showing differences in species abundances and diversity measures, despite differences in the surrounding environments.

\section{MATERIALS AND METHODS}

State of Santa Catarina, in southern Brazil, is an important area to the mangrove biogeography for representing the southernmost limit of the distribution of this kind of environment, both in the American continent and on Atlantic Ocean coasts (Woodroffe \&
GRINDOD, 1991). The climate of the region is KöEPPEN's (1948) type Cfa, i.e., subtropical with hot summers, summer temperatures above $22^{\circ} \mathrm{C}$ and rainfall in excess of $30 \mathrm{~mm}$ in the driest month. Our fieldwork was carried out in the Santa Catarina Island, municipality of Florianópolis. Only three plant species inhabit the inner woods, the trees Avicennia schaueriana (Acanthaceae), Laguncularia racemosa (Combretaceae) and Rhizophora mangle (Rhizophoraceae). The floristic diversity and exuberance of such mangroves are evidently reduced in comparison to formations in equatorial regions. The forest exhibits almost no stratification, and a canopy that is neither thick nor continuous. SouzA SoBrinHo et al. (1969) characterised these mangroves as similar in vegetation, with A. schaueriana, a tree that reaches 6-12 $\mathrm{m}$ in height, making up about three quarters of the forest. Important associated elements are the grass Spartina alterniflora (Poaceae), which forms the salt marshes, the shrub Hibiscus pernambucensis (Malvaceae) and the fern Acrostichum danaeifolium (Pteridaceae), plants that, although not reaching the inner area of the woods, occur in peripheral regions with transitional vegetation.

The three main mangrove forests of Santa Catarina Island were the target of this study: Itacorubi $\left(27^{\circ} 34^{\prime} 34^{\prime \prime} \mathrm{S}\right.$, 48 31'23'”W), Rio Tavares (27³9' 13' S, 48 32'12'W) and Ratones $\left(27^{\circ} 27^{\prime} 45^{\prime}\right.$ 'S , 48 $\left.30^{\circ} 28^{\prime \prime} \mathrm{W}\right)$. The main urban zone of the city of Florianópolis surrounds Itacorubi, located at the central region of the island. Some residential areas, pastures and forested areas surround Rio Tavares, in the southern portion of the island. Ratones is protected by an ecological station (Estação Ecológica de Carijós) in the north of the island, and is relatively far from urban areas, being surrounded by other natural environments such as the Atlantic forest, restingas (strand vegetation), fresh-water marshes and transitional types of vegetation. Using the criteria of RUSZCZYK (1986/1987) (percentage of plant cover and type and height of houses and buildings), we can classify the surroundings of each mangrove as: Itacorubi - high level of urbanisation; Rio Tavares - low to medium level of urbanisation; Ratones - no urbanisation.

One collection site was used in each of the three mangroves studied, in the inner woods. Banana-baited traps (TIDON \& SENE, 1988) were used to capture adult drosophilids. For each sample, five $\mathrm{kg}$ of banana were mashed, sprinkled with baker's yeast and distributed in 50 traps hung in the trees at about $1.5 \mathrm{~m}$ above the ground, where they were kept for three days. Samples were taken in January (summer), April (autumn), July (winter) and October (spring). We started this study in Itacorubi (number of samples $n=13$, from July 2002 to July 2005) and later expand it to Tavares $(n=8$, from October 2003 to July 2005) and Ratones ( $n=7$, from January 2004 to July 2005).

Flies were maintained in ethanol $70 \%$ until identification. The identification was made using external morphology and male terminalia, consulting specialised literature. For the analyses of male terminalia, we followed B̈̈CHLI et al. (2004). Females of sibling species were identified by their male offspring. Some individuals belonging to repleta, saltans and tripunctata groups of Drosophila that remained unidentified at species level 
were not scored for statistical analysis of species abundance and diversity measures (just $\sim 0.5 \%$ of total sample). However, they were considered in the total number of individuals $(N)$ and the number of individuals of native species. For the analysis of abundances of the two species of the willistoni subgroup of Drosophila (Drosophila paulistorum Dobzhansky \& Pavan, 1949 and D. willistoni Sturtevant, 1916), they were taken separately based only in the identified individuals. For the analysis of diversity measures, however, both identified or unidentified specimens of the subgroup were treated together, as just one taxon. Relative abundances of each species of this subgroup in the total sample were estimated for a general count of the most common species. Voucher specimens of the material collected were deposited in the Museu de Ciências Naturais, Fundação Zoobotânica do Rio Grande do Sul (MCN/FZB), Porto Alegre, RS, Brazil.

To test the null hypothesis that species abundances did not differ between the three mangroves surveyed, we performed Kruskal-Wallis tests, followed by Dunn tests when significant difference at 0.05 level was observed, with absolute abundance data of the species with at least 30 individuals collected.

To characterise the general structure of the mangrove drosophilid assemblages, the species abundance distribution was graphed as a Whittaker plot (KREBS, 1999) for the total data. The goodness-of-fit test to the observed distribution was assessed for geometric, logarithmic series and lognormal distributions, using Past 1.34 (Hammer et al., 2001). The observed species accumulation curves were constructed for each site and compared with the performance of four species richness estimators (Chao 1, Chao 2, jackknife 1 and jackknife 2) and the number of rare and infrequent species: singletons, doubletons, uniques and duplicates. BiodiversityPro version 2 (McAlEECE et al., 1997) was used to calculate the species richness estimators.

Diversity was measured as follows: (1) observed species richness $\left(S_{o b s}\right)$; $(2)$ species richness estimated by rarefaction method $\left(S_{\text {rar }}\right)$; (3) Shannon-Wiener heterogeneity index $\left(H^{\prime}\right)$; and (4) Smith-Wilson evenness index $\left(E_{v a r}\right)$. For $S_{r a r}$, all samples were standardised to 101 individuals, using BiodiversityPro version 2 (MCALEECE et al., 1997). The calculations of these last two measures were done with the software Ecological Methodology (KREBS, 1999), but we used $e$ as the log base (ln) in the formula of $H^{\prime}$. ANOVA followed by Tukey tests were performed to test the null hypothesis that there were no differences in these diversity measures between sites surveyed. The same test was carried out with the total number of individuals $(N)$. The total number of individuals of native and exotic species was also tested separately. Shapiro-Wilk tests were used to verify normality and Levene tests for homogeneity of variances. The values of $N$ (total, exotic and native) were transformed to $\ln (N+1)$.

The influence of several components on assemblage diversity was estimated by the formula $H^{\prime}$ between $=H^{\prime}{ }_{\text {total }}-\left(\sum N_{j} H^{\prime}\right) / N_{t}$; where $H^{\prime}{ }_{\text {between }}$ is the value of $H^{\prime}$ to a given component; $H^{\prime}$ total is the value of $H^{\prime}$ considering all the samples together; $N_{t}$ is the total number of individuals in all samples, $N_{j}$ is the number of individuals in category $j, H^{\prime}{ }_{j}$ is $H^{\prime}$ within category $j$. The components considered were: years (with categories 1, 2, 3), seasons (winter, spring, summer, autumn), sampling occasions (July 2002, October 2002, January 2003, April 2003 and so on, until July 2005) and sites (Itacorubi, Tavares and Ratones).

\section{RESULTS AND DISCUSSION}

A total of 82,942 drosophilids were collected in the 28 samples taken in the three mangrove forests of Santa Catarina Island (Itacorubi: $N=32,800, S_{o b s}=51, n=13$; Rio Tavares: $N=24,804, S_{o b s}=48, n=8$; Ratones: $N=25,338$, $\left.S_{o b s}=45, n=7\right)$. Five genera, 69 species and 58 species of Drosophila $(N=78,484)$, six of Zygothrica Wiedemann, $1830(N=13)$, two of Amiota Loew, $1862(N=14)$, and one of Leucophenga Mik, $1886(N=1)$, Scaptodrosophila Duda, $1923(N=29)$ and Zaprionus Coquillett, 1901 $(N=4,401)$ were present. The most common species were D. simulans Sturtevant, 1919 (56\% of the total Drosophilidae sample), D. malerkotliana Parshad \& Paika, 1964 (21\%), Zaprionus indianus Gupta, 1970 (5\%), D. mediostriata Duda, 1925 (5\%), D. willistoni (5\%), D. paulistorum (3\%), D. repleta Wollaston, 1858 (1\%), D. polymorpha Dobzhansky \& Pavan, 1943 (1\%) and D. mercatorum Patterson \& Wheeler, 1942 (1\%). The complete species list with respective abundances and additional discussion is available in ScHMITz et al. (2007).

The following species were tested for possible differences in absolute abundance between sites: $D$. ananassae Doleschall, 1858, D. melanogaster Meigen, 1830, D. malerkotliana, D. simulans (melanogaster group), D. capricorni Dobzhansky \& Pavan, 1943, D. nebulosa Sturtevant, 1916, D. paulistorum, D. willistoni (willistoni group), D. sturtevanti Duda, 1927 (saltans group), D. hydei Sturtevant, 1921, D. mercatorum, D. repleta (repleta group), D. neocardini Streisinger, 1946, D. polymorpha (cardini group), D. griseolineata Duda, 1927 (guarani group), D. mediostriata (tripunctata group), D. pallidipennis Dobzhansky \& Pavan, 1943 (pallidipennis group), D. caponei Pavan \& da Cunha, 1947 (caponei group) and Z. indianus (armatus group). The null hypothesis of similar abundances between sites was rejected only for $D$. mercatorum $\left(H c_{2}=9.12, P=0.011\right)$, which presented significantly lower abundances in Ratones as compared to Itacorubi $\left(Q_{3}=2.68, P<0.05\right)$ and Rio Tavares $\left(Q_{3}=2.71, P<0.05\right)$. Also, there was no significant difference in abundance between sites when considering all individuals of native species $\left(F_{2.25}=2.69\right.$, $P=0.088)$ or of exotic species $\left(F_{2.25}=0.17, P=0.845\right)$.

The species abundance distribution of the total data (Fig. 1) showed that a large proportion of the species were relatively uncommon, while a few species were very abundant. The ten most abundant species accounted for $99 \%$ of the individuals, while 41 out of the 69 species $(59 \%)$ were represented by less than 10 individuals, including 17 singletons (25\%). The observed abundance distribution did not fit to geometric and log-series models, but to a lognormal distribution (mean=-1.492, variance $=4.454, P=0.580$ ).

The species accumulation curves, the number of rare and infrequent species, and the performance of four species richness estimators showed no remarkable difference between the three mangroves studied (Fig. 2). 


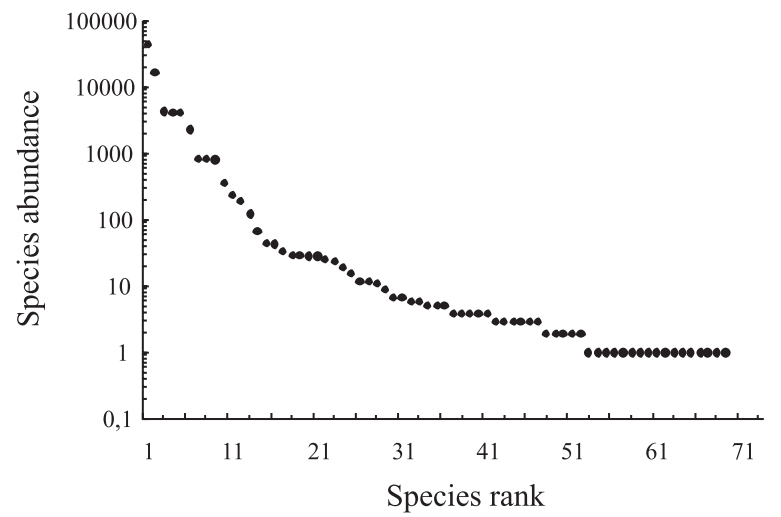

Figure 1. Rank-abundance distribution for the total data of drosophilids in mangrove forests of Santa Catarina Island.
There was a large superposition range in the species richness estimates, which varied from 59.00 to 140.73 in Itacorubi $\left(S_{o b s}=51 ; n=13\right), 62.75$ to 109.24 in Rio Tavares $\left(S_{o b s}=48 ; n=8\right)$ and 63.71 to 132.17 in Ratones $\left(S_{o b s}=45\right.$; $n=7)$. The estimators jackknife 1 and jackknife 2 showed very similar patterns in all sites, while Chao 1 and Chao 2 were more irregular, although not showing a consistent pattern of higher diversity in any site. In general, species accumulation curves kept a slight ascending trend at the end of samples, while the number of rare species did not decrease.

The diversity measures showed similar features in the three mangrove sites searched (Tab. I). No significant difference was found comparing values of $S_{o b s}\left(F_{2.25}=0.05\right.$, $P=0.955), S_{\text {rar }}\left(F_{2.25}=1.84, P=0.180\right), H^{\prime}\left(F_{2.25}=0.22\right.$,
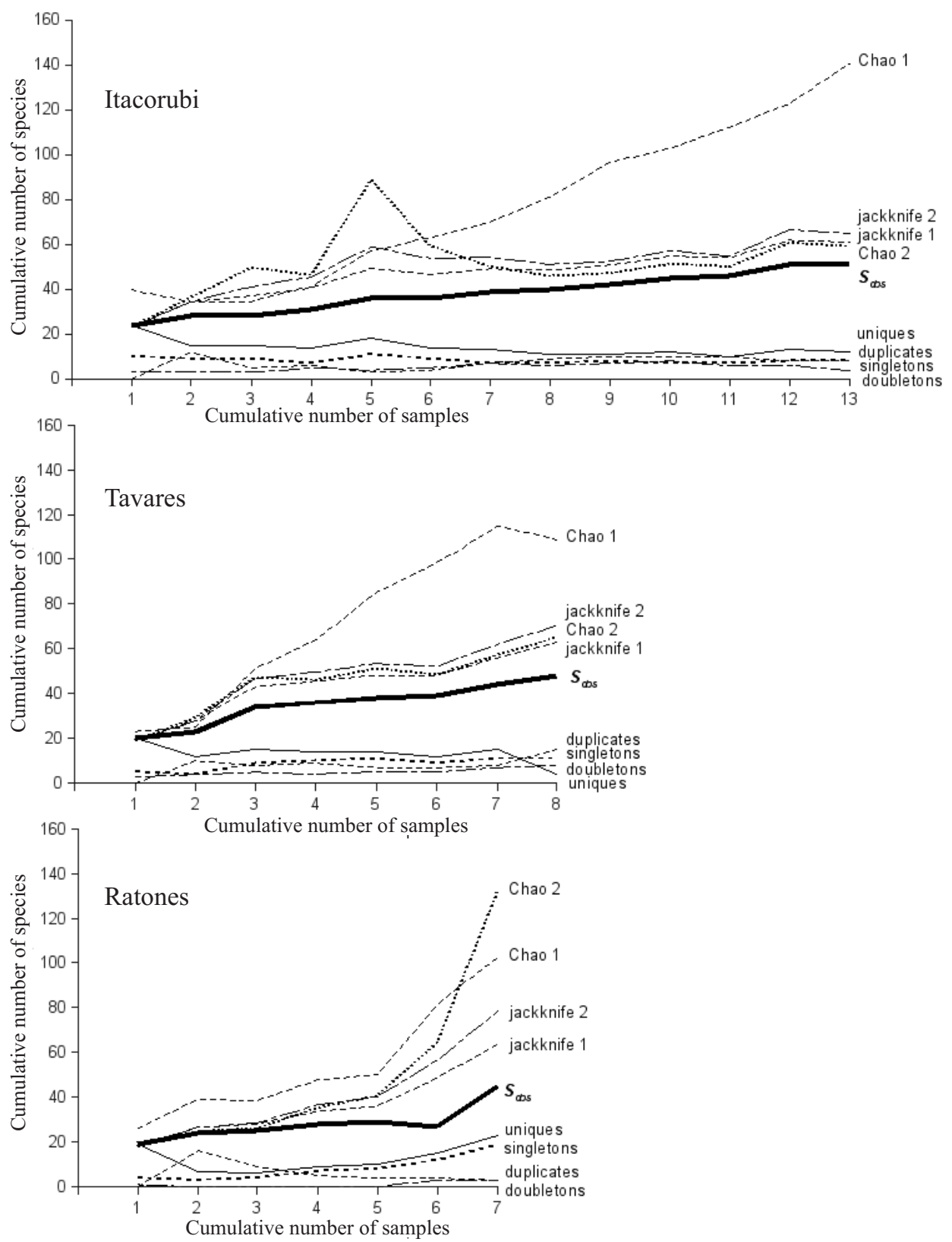

Figure 2. Plots comparing the performance of the species richness estimators (Chao 1, Chao 2, jackknife 1, jackknife 2) with the observed species accumulation curve $\left(S_{\text {obs }}\right)$ and the number of rare (singletons, doubletons) and infrequent species (uniques, duplicates), using data from the drosophilid samples of Itacorubi, Rio Tavares and Ratones mangroves, Santa Catarina Island. 
Table I. Diversity measures for the mangrove drosophild assemblages of Santa Catarina Island in each site and total data (mean \pm standard deviation) ( $n$, number of samples (each sample constituted by 50 traps/three days at field); $S_{o b s}$, observed species richness; $S_{r a r}$, species richness estimated by rarefaction (for 101 individuals); $H^{\prime}$, Shannon-Wiener heterogeneity index; $E_{v a r}$, Smith-Wilson evenness index; $N$, number of individuals; no statistical difference was found between sites).

\begin{tabular}{lccc}
\hline & Itacorubi $(n=13)$ & Rio Tavares $(n=8)$ & Ratones $(n=7)$ \\
\hline$S_{\text {obs }}$ & $17.8 \pm 4.27$ & $18.4 \pm 5.13$ & $17.7 \pm 5.88$ \\
$S_{\text {rar }}$ & $7.5 \pm 1.63$ & $7.7 \pm 2.09$ & $9.2 \pm 2.38$ \\
$H^{\prime}$ & $1.20 \pm 0.323$ & $1.08 \pm 0.433$ & $1.17 \pm 0.352$ \\
$E_{v a r}$ & $0.15 \pm 0.046$ & $0.18 \pm 0.084$ & $0.23 \pm 0.093$ \\
$N$ & $2.523 \pm 2.959$ & $3.100 \pm 4.202$ & $3.619 \pm 7.458$ \\
\hline
\end{tabular}

Table II. Niche analysis, showing partitioning of diversity for temporal and spatial changes in the mangrove drosophilid assemblages of Santa Catarina Island.

\begin{tabular}{lcr}
\hline Niche component & \multicolumn{2}{c}{$\begin{array}{c}\text { Contribution to diversity } \\
\text { \% total }\end{array}$} \\
\hline Sites & 0.110 & 7.80 \\
Years & 0.098 & 6.91 \\
Seasons & 0.172 & 12.18 \\
Sampling occasions & 0.281 & 19.88 \\
Not explained & 0.752 & 53.23 \\
Total & 1.413 & 100.00 \\
\hline
\end{tabular}

$P=0.806), E_{\text {var }}\left(F_{2.25}=2.60, P=0.094\right)$ and $N\left(F_{2.25}=0.78\right.$, $P=0.469)$ between the sites.

Table II shows the partitioning of diversity for temporal and spatial changes. The spatial component (sites) showed a relatively low importance. The contribution of the seasonal variation were higher than the annual one, but a large amount of variation was due to factors not related to seasons or years, as seen by the high contribution of the sampling occasions component. Additionally, more than half of the diversity could not be explained by the components analysed.

The general results of this study suggest that the drosophilid assemblages of the mangrove forests of Santa Catarina Island were very similar to one other. This was noticed due to the lack of statistical differentiation of the absolute abundances of 16 out of the 17 most common species, of the total number of individuals $(N)$, the number of individuals of native and exotic species, of the diversity measures $\left(H^{\prime}, S_{o b s}, S_{r a r}\right.$ and $\mathrm{E}_{\mathrm{var}} ;$ Tab. I), as well as in the light of the similar patterns of the species accumulation curves, the species richness estimators and the number of rare and infrequent species (Fig. 2), and the low importance of the spatial component in the analyses of partitioning of the diversity (Tab. II).

Furthermore, our experimental design can be considered a temporal pseudoreplication (KREBS, 1999), and violates the assumption that each observation is independent. This adds a bias increasing type I error probability, i.e., the probability of finding a significant difference where it does not exist. However, even with such a bias, the analysis did not find any significant difference, reinforcing the homogeneity of drosophilid assemblages in all the mangroves studied. Additionally, regarding species abundances, even the only species that showed statistical difference (D. mercatorum) may be considered doubtful, since with an $\alpha=0.05$, the type I error probability (reject incorrectly the null hypothesis) is $5 \%$, and we have one significant difference out of 17 comparisons (the number of species tested), i.e., 1/ $17=0.059$, that is $\sim 5 \%$.

This homogeneity can also be seen when an analysis of similarity in the species composition with the coefficient of Jaccard (KREBS, 1999) is carried out. We found values of $S_{j}=0.65$ for Itacorubi versus Tavares, $S_{\mathrm{j}}=0.55$ for Itacorubi versus Ratones and $S_{i}=0.58$ for Rio Tavares versus Ratones. This means that the mangroves share more than $50 \%$ of the species. They differ, in fact, only in the occurrence of the rare species. A similarity even higher than that is obtained with Morisita's index (KREBS, 1999), which takes into account the relative abundances of the species. We found $C_{\lambda}=0.86$ for Itacorubi versus Rio Tavares, $C_{\lambda}=0.95$ for Itacorubi versus Ratones and $C_{\lambda}=0.82$ for Rio Tavares versus Ratones. This shows that the relative abundances of the species are also very similar in all the mangroves.

This homogeneity in the mangrove drosophilid assemblages occurs despite the contrasting types of environments and levels of urbanization of the surroundings of each forest. Responses to different levels of urbanisation were found in drosophilid assemblages in Oxford, USA (AvondET et al., 2003), in Brasília, Central Brazil, (FerReira \& Tidon, 2005) and even in Santa Catarina Island (GotTschalk et al., 2007). However, the homogeneity of the mangrove forests seems to be a stronger factor as compared to the heterogeneity in their surrounding environments, not being so important if the mangrove is located within a city or in a natural reserve. Thus, taking into account our two initial alternative hypotheses, which were: (1) species abundances and diversity measures of mangrove drosophilid assemblages respond to the differences in the environments surrounding the mangroves; and (2) mangrove forests of the same region have typical drosophilid assemblages, not showing differences in species abundances and diversity measures, despite differences in the surrounding environments, for the drosophilid assemblages of the mangrove forests of Santa Catarina Island, we have to choose the latter.

Now, considering the high similarity in the species abundances and the diversity measures of the drosophilid assemblages of the mangrove forests of Santa Catarina Island, we can characterise such assemblages as presenting an unexpectedly high species richness (Tab. I; Fig. 2) and a heterogeneity index $\left(H^{\prime}\right)$ comparable to other environments in the Santa Catarina Island, as the Atlantic Rain Forest and the city (DE Toni et al., 2007; Gottschalk et al., 2007). They also show a high 
dominance of a few common species, as seen by the low evenness index $\left(E_{v a r}\right)$ and the lognormal distribution of the rank-abundance plot (Fig. 1). Actually, applying the Occurrence Constancy Method of DAJOz (1983) (the constancy value, $c$, is the number of collections in which the species occurred divided by the total number of collections, and multiplied by 100), $62.3 \%$ (43) of the species found can be classified as accidental $(c<25), 20.3 \%$ (14) as accessory $(25 \leq \mathrm{c}<50)$ and only $14.4 \%(12)$ as constant (c $\geq 50)$.

As discussed before, the relatively low contribution of the spatial component (sites) in the analysis of partitioning of diversity (Tab. II) suggests the homogeneity of the drosophilid assemblages in the mangroves of Santa Catarina Island. Additionally, the contribution of the seasonal variation found in the mangroves was very similar to that of the urban parks of Porto Alegre (SILVA et al., 2005), but lower than in other studies (SHORROCKs, 1975, in English forest; BENADO \& Brncic, 1994, in Chile; De Toni et al., 2007, in Atlantic Forest in Santa Catarina Island and vicinities). The annual variation contributed to a lesser extent, but relatively higher in the mangroves when compared with the studies above-mentioned (about half of the contribution of the seasonal component in the mangroves, compared with one fifth or less in the others). Furthermore, variation unrelated to cyclic processes is also important (see the sampling occasion component).

Applying again an analysis of similarity with Morisita's index, now comparing the mangrove assemblages with those from Atlantic Forest and urban zones (De Toni et al., 2007; GotTschalk et al., 2007) already known in Santa Catarina Island and vicinities, we found the following picture: the mean similarity between the mangrove assemblages is around $C_{\lambda}=0.88$; when mangrove assemblages are compared with the urban ones the mean value is $C_{\lambda}=0.57$; with the Atlantic Forest assemblages, it drops to $C_{\lambda}=0.32$.

The major similarity between mangrove forests and urban environments when compared with the Atlantic forest may be a result of the very strong presence of exotic species (originated from out of Neotropics) in the mangroves. The three most abundant species in the mangroves were exotic: $D$. simulans, $D$. malerkotliana and $Z$. indianus. The other exotic species were $D$. ananassae, D. busckii Coquillett, 1901, D. immigrans Sturtevant, 1921, D. kikkawai Burla, 1954, D. melanogaster, D. virilis Sturtevant, 1916 and $S$. latifasciaeformis (Duda, 1940). Together, the exotic specimens accounted for $83 \%$ of all specimens captured, and were dominant not only for a mangrove situated within an urban zone, but also for one located in a conservation area with native vegetation. These species also dominate in the urban environments (FERREIRA \& TIDON, 2005; SILVA et al., 2005; GotTschalk et al., 2007), as compared to those from the Atlantic Forest, where they are replaced by native species, especially those of the willistoni group (SAAVEDRA et al., 1995; De Toni et al., 2007). The urban zones may be characterised as open, well-lit and xeric environments. Such conditions, however, can also be found in some natural environments, as the southern grasses, studied in Rio Grande do Sul, Brazil, by SAAVEDRA et al. (1995), whose assemblage was dominated by $D$. simulans. Tidon (2006) studied two contrasting environments in the Cerrado biome, in central Brazil, and found higher abundance of exotic species in the open savannas than in the gallery forests. In addition to the exotic species, others that seem to have their abundances increased in mangrove forests are more related to xeric environments. The most common species from repleta group, for instance, were $D$. repleta and $D$. hydei, which are species originated in Mexican deserts (they can even be considered exotic in Brazilian environments), and $D$. mercatorum, another species with preferences for open habitats (TIDON, 2006). In contrast, the typical forestdwelling species of the group were rare. Similarly, $D$. mediostriata, found both in savannas and gallery forests by TIDOn (2006) and in xerophytic vegetation by MATEus et al. (2006), was by far the most abundant species of the tripunctata group, while its forest relatives were much rarer. Even in the willistoni group, the most common species in the mangroves were $D$. willistoni and $D$. paulistorum (willistoni subgroup), which, in spite of being more abundant in the forests (SAAVEDRA et al., 1995; Tidon, 2006), are still the most abundant of the group also in other environments (SILva et al., 2005; Tidon, 2006). In addition, $D$. nebulosa, the only species of bocainensis subgroup that prefers open environments (VAL et al., 1981), was more abundant than other species of the subgroup, an inverse situation found by DE TONI et al. (2007) in the Atlantic Forest. Despite being a forest, probably the mangrove forests should be more appropriately interpreted as xeric environments. At first, it may be difficult to consider a swamp as a dry environment, but mangroves are salt-water swamps, and salinity may act as a desiccation factor. Furthermore, the forest is not dense and shady, permitting a relatively high luminosity in its interior. So, the abiotic conditions of mangrove forests may be of an intermediate nature, between those of forested and open environments, but probably more similar to the latter.

Values of $S_{o b s}$ found by us for the three mangrove drosophilid assemblages were similar to those found by DE Toni et al. (2007) in eight points of Atlantic Forest in Santa Catarina Island and vicinities, using the same sampling effort in each collection. Furthermore, species accumulation curves and richness estimators (Fig. 2) suggest that, despite the large number of specimens already collected, more species could be found using more samples. Compared with the Atlantic Forest, though, the mangroves show very harsh conditions, especially for terrestrial insects associated with fruits, such as drosophilids, due to their close contact with the sea and the very low floristic diversity. In contrast with the extreme high-diversity flora within the Atlantic Forest, only three species of plants are present in the inner mangroves. This fact, however, did not reduce the diversity of drosophilids to the same extent.

But how can this diversity be maintained in such a harsh environment as the mangrove forests, apparently so poor in resources for drosophilids? We have conducted a field survey in order to detect the natural breeding sites used by the drosophilids in the mangroves and we could not rear any fly from fruits and flowers of 
any of the only three species of plants that inhabit the deeper forest (Avicennia schaueriana, Laguncularia racemosa and Rhizophora mangle). Actually, their fruits seem too dry and hard, and their flowers too small to represent suitable resources. Some fleshy fungi (Auricularia sp.) collected inside the mangrove and flowers of some plants found in the borders of the forests (Ipomoea cairica (Convolvulaceae) and $I$. aff. chiliantha) were shown to be used by specialised species, very rare or even absent in our traps (Zygothrica sp. in fungi and D. bromelioides Pavan \& da Cunha, 1947 and D. lutzii Sturtevant, 1916 in flowers). The only exception was the decaying flowers of Hibiscus pernambucensis, from which we observed the emergence of many specimens of $D$. mediostriata. This shrub, although not reaching the inner woods, is the most common element of the periphery of the mangroves, besides the typical mangrove trees. Drosophila mediostriata is a species generally rare in other environments, but we collected it in high abundances in the mangroves, probably as a result of its association with that plant. No other potential resource was recognised and, actually, flies were never observed inside the mangroves a long way from traps. Also, it is important to consider that any potential resource that could be present on the forest floor would be subject to the action of tides, i.e., to flooding, mechanical transport and salinity.

Due to this lack of resources for drosophilids in the mangrove forests, it is very improbable that most of the drosophilid flies found in the mangroves are really local residents. They may represent, more possibly, migrants from the adjacent areas. Studies on drosophilid dispersion, as those of CoYNe et al. (1982, 1987), showed that flies can disperse randomly, even leaving favourable areas to reach desolate ones many kilometres away. If a similar process is operating here, it could explain the presence of drosophilids in the mangroves even with the absence of breeding resources. In this case, the mangrove forests would be acting as a sink. The neighbouring areas close to the mangroves, where flies can find suitable breeding sites more abundantly, could be the sources of immigrants during a random dispersion or being attracted for the baited-traps. So, maybe we should consider drosophilids in mangrove forests as passer-by visitors, making exceptions probably only for $D$. mediostriata (breeding in $H$. pernambucensis flowers) and a few specialised species in localised resources (e. g. fungi). Actually, even the presence of D. mediostriata in the inner woods must not be maintained without dispersion from the borders, where its host plant is found.

This source-sink system may be considered as a suitable hypotheses to explain the unexpectedly high species diversity of drosophilids in the mangroves in face of the lack of resources. Pulliam (1988), for instance, defends that the diversity and relative abundance of the organisms in any particular habitat may depend as much on the regional diversity of habitats as on the diversity of resources locally available. So, perhaps the upper limit for the species richness in the mangrove forests is, in fact, not lower than the total regional pool. This sourcesink hypotheses, however, needs further confirmation, and studies on the dispersion behaviour of natural populations are required.
The homogeneity of the species abundances in the three mangroves surveyed, contrasting to their different surrounding environments, though, seems to be a paradox. However, the Ratones mangrove, for example, even situated far from the urban zones, could be colonised by exotic and other species related to xeric environments from some natural open and xeric landscape, as restingas (strand vegetation) and shrubby vegetation. On the other hand, most native species did not suffer any decrease in absolute abundance in the urban areas of Santa Catarina Island, when compared to an Atlantic Rain forest site. So, this could explain why the absolute abundance of the native species also did not decrease in a mangrove surrounded by the city, as Itacorubi.

If most of the drosophilids found in the mangrove forests are migrants from surrounding areas, the relative abundance of species with high dispersion ability may be increased, since species with lower dispersion ability may not reach the inner mangroves with the same success. This agrees with the type of drosophilid more commonly found in the mangroves, i.e., those related to open environments, as exotic species and others. However, as we have seen, the structure of the assemblages of drosophilids in mangrove forests is typical and does not seem to be highly similar with surrounding environments. So, if the mangrove forests are really being reached by species coming from other areas, this process may be selective, as if the conditions of that environment represent a filter imposed to the flies. Different species might perform this supposed dispersion more or less successfully, maybe due to their dispersion ability, behaviour or sensitivity to environmental stresses, so that the result is a distinctive mangrove assemblage, with the relative abundance of each species modified during the process.

Acknowledgments. We are grateful to members of the Laboratório de Drosofilídeos (UFSC) and Laboratório de Drosophila (UFRGS) for helping in collection trips, identification and discussion, especially to Dr. Marco S. Gottschalk, Msc. Luís E. M. Bizzo, Msc. Jonas S. Döge, Msc. Sabrina C. F. de Oliveira and Dr. Daniela C. De Toni. Thanks also to Estação Ecológica de Carijós, for permitting the collections in Ratones, and to Drs Rosana Tidon and Helena P. Romanowski for suggestions and commentaries on an early version of the manuscript. We thank the two anonymous referees for valuable suggestions as well. This research was supported by grants and fellowships from CNPq, CAPES, FAPERGS and PROPESQ-UFRGS.

\section{REFERENCES}

Avondet, J. L.; Blair, R. B.; Berg, D. J. \& Ebbert, M. A. 2003. Drosophila (Diptera: Drosophilidae) response to changes in ecological parameters across an urban gradient. Environmental Entomology 32:347-358.

Bächli, G.; Vilela, C. R.; Escher, S. A. \& Saura, A. 2004. The Drosophilidae (Diptera) of Fennoscandia and Denmark. Fauna Entomologica Scandinavica 39:1-362.

Benado, M. \& BRncic, D. 1994. An eight year phenological study of a local drosophilid community in Central Chile. Zeitschrift fur Zoologische Systematik und Evolutionsforschung 32:51-63.

Carson, H. L. 1971. The ecology of Drosophila breeding sites. Honolulu, Harold L. Lyon Arboretum Lecture 2, University of Hawaii. 27p.

Cintrón, G. \& Schaeffer-Novelli, Y. 1980. Introdución a la ecología del manglar. São Paulo, Department of Natural Resources \& Instituto Oceanográfico da USP. 146p. 
Coyne, J. A.; Boussy, I. A.; Prout, T.; Bryant, S. H.; Jones, J. S. \& Moore, J. A. 1982. Long-distance migration of Drosophila. The American Naturalist 119:589-595.

Coyne, J. A.; Bryant, S. H. \& Turelli, M. 1987. Long-distance migration of Drosophila. 2. Presence in desolate sites and dispersal near a desert oasis. The American Naturalist 129:847-861.

Cunha, A. B. \& Magalhães, L. E. 1965. A ecologia e a genética de populações de drosófila no Brasil. Ciência e Cultura 17:525527

DAJoz, R. 1983. Ecologia geral. Petrópolis, Editora Vozes. $471 \mathrm{p}$.

De Toni, D. C.; Gottschalk, M. S.; Cordeiro, J.; Hofmann, P. R. P. \& Valente, V. L. S. 2007. Study of the Drosophilidae (Diptera) assemblages on Atlantic Forest islands of Santa Catarina State. Neotropical Entomology 36:356-375.

De Toni, D. C. \& Hofmann, P. R. P. 1995. Preliminary taxonomic survey of the genus Drosophila (Diptera, Drosophilidae) at Morro da Lagoa da Conceição, Santa Catarina, Brazil. Revista Brasileira de Biologia 55:347-350.

Dobzhansky, T. \& PAVAN, C. 1950. Local and seasonal variations in relative frequencies of species of Drosophila in Brazil. Journal of Animal Ecology 19:1-14

Ferreira, L. B. \& Tidon, R. 2005. Colonizing potential of Drosophilidae (Insecta, Diptera) in environments with different grades of urbanization. Biodiversity and Conservation 14:1809-1821.

Gottschalk, M. S.; De Toni, D. C.; Hofmann, P. R. P. \& Valente, V. L. S. 2007. Changes in Brazilian Drosophilidae (Diptera) assemblages across an urbanisation gradient. Neotropical Entomology 36:848-862.

Hammer, Ø.; Harper, D. A. T. \& Ryan, P. D. 2001. PAST: Palaeontological Statistics software for education and data analysis. Palaeontologia Electronica 4: 1-9. Available at: <http://palaeo-electronica.org/2001_1/past/issue1_01.htm>. Accessed on: 04.2009

Holt, R. D.; Barfield, M. \& Gonzalez, A. 2003. Impacts of environmental variability in open populations and communities: "inflation" in sink environments. Theoretical Population Biology 64:315-330.

KöEPPEN, W. 1948. Climatologia: con un estúdio de los climas de la Tierra. Mexico City, Fondo de Cultura Económica. 478p.

KREBS, C. J. 1999. Ecological methodology. Menlo Park, Addison Wesley Longman. 620p.

Krijger, C. L. 2000. Spatio-temporal heterogeneity and local insect diversity - a case study in neotropical Drosophila communities. Leiden, Proefschrift Universiteit Leiden. $179 \mathrm{p}$

Mateus, R. P.; Buschini, M. L. T. \& Sene, F. M. 2006. The Drosophila community in xerophytic vegetations of the upper Parana-Paraguay river basin. Brazilian Journal of Biology 66:719-729.
McAleece, N.; Lambshead, P. J. D. Paterson, G. L. J. \& Gage, J. D. 1997. BioDiversity Professional version 2. Available at: <http://www.sams.ac.uk/activities/downloads/downloads.htm>. Accessed on: 04.2009.

Pulliam, H. R. 1988. Sources, sinks, and population regulation. The American Naturalist 132:652-661.

RusZCZYK, A. 1986/1987. Análise da cobertura vegetal da cidade de Porto Alegre, RS. Revista Brasileira de Botânica 9:225229.

SaAvedra, C. C. R.; Callegari-Jacques, S. M.; Napp, M. \& Valente, V. L. S. 1995. A descriptive and analytical study of four Neotropical drosophilid communities. Journal of Zoological Systematics and Evolutionary Research 33:62-74.

SchmidA, A. \& Wilson, M. V. 1985. Biological determinants of species diversity. Journal of Biogeography 12:1-20.

Schmitz, H. J.; Valente, V. L. S. \& Hofmann, P. R. P. 2007. Taxonomic survey of Drosophilidae (Diptera) from mangrove forests of Santa Catarina Island, southern Brazil. Neotropical Entomology 36:53-64

Sene, F. M.; Val, F. C.; Vilela, C. R. \& Pereira, M. A. Q. R. 1980 Preliminary data on the geographical distribution of Drosophila species within morphoclimatic domains of Brazil. Papéis Avulsos de Zoologia 33:315-326.

SHORROCKS, B. 1975. The distribution and abundance of woodland species of British Drosophila (Diptera: Drosophilidae). Journal of Animal Ecology 44:851-864

Silva, N. M.; Fantinel, C. C.; Valente, V. L. S. \& Valiati, V. H. 2005. Population dynamics of the invasive species Zaprionus indianus (Gupta) (Diptera: Drosophilidae) in communities of drosophilids of Porto Alegre city, southern of Brazil. Neotropical Entomology 34:63-374.

Souza Sobrinho, R. J. S.; Bresolin, A. \& Klein, R. M. 1969. Os manguezais na Ilha de Santa Catarina. Insula 2:1-21.

Thomas, C. D. \& Kunin, W. E. 1999. The spatial structure of populations. Journal of Animal Ecology 68:647-657.

Tidon, R. 2006. Relationships between drosophilids (Diptera, Drosophilidae) and the environment in two contrasting tropical vegetations. Biological Journal of the Linnean Society 87:233-247.

Tidon, R. \& Sene, F. M. 1988. A trap that retains and keeps Drosophila alive. Drosophila Information Service 67:89.

Val, F. C.; Vilela, C. R. \& Marques, M. D. 1981. Drosophilidae of the Neotropical Region. In: Ashburner, M.; Carson, H. L. \& Thompson JR., J. N. eds. The genetics and biology of Drosophila. London, Academic. p.123-168.

Valiela, I.; Bowen, J. L. \& York, J. K. 2001. Mangrove forests one of the world's threatened major tropical environments. Bioscience 51:807-815.

Watkinson, A. R. \& Sutherland, W. J. 1995. Sources, sinks and pseudo-sinks. Journal of Animal Ecology 64:126-130.

Woodroffe, C. D. \& Grindrod, J. 1991. Mangrove biogeography: the role of quaternary environmental and sea-level change. Journal of Biogeography 18:479-492. 